\title{
Response of Soybean Lines to Drought Stress During Reproductive Phase
}

\author{
Suhartina ${ }^{1}$ Purwantoro ${ }^{1}$ Novita Nugrahaeni ${ }^{1,{ }^{*}}$ Made Jana Mejaya ${ }^{1}$ \\ ${ }^{1}$ Indonesian Legumes and Tuber Crops Research Institute (ILETRI). Jl. Raya Kendalpayak km.8, PO Box 66 Malang \\ 65101, East Java, Indonesia. \\ *Corresponding author. Email: nnugrahaeni@gmail.com
}

\begin{abstract}
At production centers, soybeans are in a rice-paddy-soybean or paddy-soybean cropping pattern, which is often at risk of crop failure due to drought. Therefore, it is necessary to develop varieties that are more tolerant to drought than existing varieties. The aim of this study was to evaluate soybean lines to drought stress during the reproductive phase. The research was conducted at Ngawi, East Java during dry season of 2016. A total of 34 soybean lines and two check varieties (Grobogan and Dering 1) were tested using a randomized block design and repeated three times. The study consisted of two growing environments, namely optimal conditions (irrigation between planting and R7 phase at intervals of 10-15 days) and drought conditions in the reproductive phase (irrigation was carried out between planting and R2 at intervals of 10-15 days). Drought stress tolerance lines were identified based on their stress tolerance indexes (STI). Research result revealed that five soybean lines were more tolerant than Dering 1 (drought tolerant check), with a stress tolerance index (STI) values of 1.20 to 1.35, which was higher than Dering 1 (STI 1.02) and Grobogan (STI 1.04). Among those five lines, TGm-161-25-10 line, produced the highest seed yield both in the optimal and drought conditions, i.e. $2.60 \mathrm{t} / \mathrm{ha}$ and $2.44 \mathrm{t} / \mathrm{ha}$, respectively. Those five selected droughttolerant lines were early maturing with maturity days ranged from 75.0 to 77.3 days and three of those were belong to large seed sizes, i.e. 14.6-15.4 g/100 seeds.
\end{abstract}

Keywords: drought tolerant, reproductive phase, seed yield, soybean

\section{INTRODUCTION}

Soybean [Glycine max L (Merr.)] plays an important role in people's daily menu in Indonesia, and most of its usage is for tempeh and tofu production. However, despite of the high demand, the government is still imported it in a quite large volume to meet the demand. In 2018, $86.4 \%$ of the domestic demand was fulfilled from import [1].

Soybean is planted in the second dry season on lowland areas or during the first dry season on rainfed areas. Under such agroecosystems, soybean frequently encountered drought stress due to uncertainty of rainfall or water scarcity. The soybean performance impaired by high temperature and water-shortage stress. Soybean seed deteriorated more seriousely when it experienced water stress at the reproductive phase as compared to when it experienced water stress the vegetative phase. High temperature and water-deficit stress significantly affected seed quality as determined by germination percentage, seedling vigor index, electrical conductivity, tetrazolium vigor test, oil and protein content [2,3]. Drought stress during R3, R5, and R6 phases decreased the seeds yield by $33 \%, 31 \%$, and $50 \%$, respectively [4]. Drought stress in $50 \%$ of available water reduced the yield of Cikuray, Panderman, Burangrang, Tidar, and Wilis, the existing improved varieties, ranged from $41.7 \%$ to $64.0 \%$ [5].

The risk of decreasing yield can be reduced through an environmental manipulation approach and 
cultivating drought-tolerant soybean varieties. Planting drought-tolerant varieties on those droughtprone areas provides a great opportunity for increasing soybean production.

Soybean consumers (farmers and tempeh food producers) prefer varieties with high yield, early maturity and large seed [6,7]. The current drought tolerant soybean variety Dering 1 is a medium in maturity (81 days) and medium in seed size (10.7 g/100 seeds) [8]. Developing variety that earlier maturing and larger seed size compare to the existing improved cultivar Dering 1 variety would provide opportunities to minimize the risk of crop failures and problems of soil health. Breeding to improve Dering 1 was started in 2010 by making crosses between the Dering 1 variety with other gene sources which were early maturing and larger seed size. Those gene sources were obtained from germplasm evaluation and identification for drought tolerant. Those were used for establishing population through artificial hybridization in 2010. We bulked the hybrid seed to obtain F3 generation seed. Selection from (F3-F5) generations using pedigri method with selection criteria was agronomic performance especially maturity. Selection environment was drought stress during reproductive stage throughout the generations. F6 generation was used for preliminary yield trial, and followed by advanced yield trial during 20162017. During the yield trials STI was used as selection criteria. Those breeding program has resulted 34 homozygous lines. The objective of this study was to evaluate those soybean lines that were drought tolerant in the reproductive phase and early maturity (<80 days).

\section{MATERIALS AND METHODS}

The research was conducted at Ngawi, East Java during the dry season of 2016. A total of 34 soybean lines and two check varieties (Grobogan and Dering 1) were tested using a randomized completely block design and repeated three times. The study included of two growing environments, namely optimal conditions (irrigation between planting and R7 phase at intervals of 10-15 days) and drought conditions in the reproductive phase (irrigation was carried out between planting and R2 at intervals of 10-15 days). Planting distance was $40 \mathrm{~cm} \mathrm{x} 15 \mathrm{~cm}$, two plants per hill. Plot size was $2.0 \mathrm{~m}$ x $3.3 \mathrm{~m}$. Selection criteria was Stress tolerance index (STI). The higher the STI value, the higher the drought tolerance of a line. Stress tolerance index is used to identify and select genotypes which were able to give high seed yield both in an optimal and drought stress condition [9].
The STI value was calculated based on the following formula:

Stress tolerance index $(S T I)=\frac{H p x H c}{(H p a v)^{2}}$

Where, Hp and Hc is seed yield under optimal condition and drought stress condition, respectively. Whereas Hpav is mean of all genotypes under optimal condition.

Drought response criteria STI among the tested soybean lines following methods developed by Doreste et al [10], classified into five categories, i.e.:

1. Highly tolerant (HT) : $(\mathrm{X}>\bar{X}+2$ sd $)$

2. Tolerant (T) $(\bar{X}+\mathrm{sd}<\mathrm{X} \leq \bar{X}+2$ sd $)$

3. Moderately tolerant (MT) $(\bar{X}-$ sd $<\mathrm{X} \leq \bar{X}+$ sd ).

4. Susceptible (S) $(\bar{X}-2$ sd $<\mathrm{X} \leq \bar{X}$ - sd)

5. Highly susceptible (HS) $(\mathrm{X} \leq \bar{X}-2$ sd),

Where, $\bar{X}$ and sd is mean value and standard deviation of STI, respectively.

\section{RESULT AND DISCUSSION}

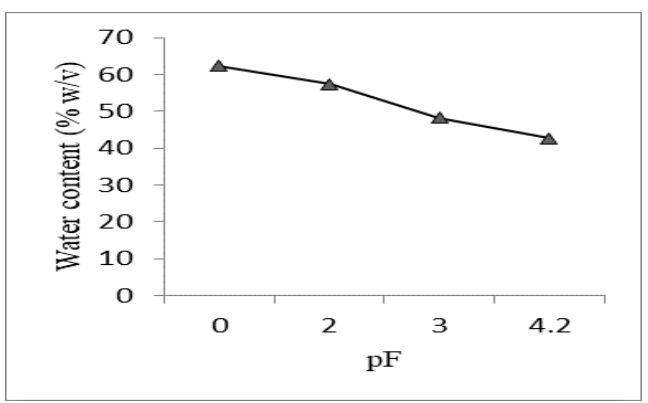

Figure 1. Soil moisture content at various $\mathrm{pF}$ values at Ngawi, East Java

The moisture content of the soil from the flowering to harvest phase showed a decrease. The actual moisture content of the soil from 50 days old plant (starting to fill the pods) to the age of 73 days was equivalent to $\mathrm{pF} 3.0$ and even closer to $\mathrm{pF} 4.2$ (Figure 1 and Table 1). This showed that since filling the pods stage until pods maturity, plants experienced drought stress. 
Table 1. Soil water content from flowering (34 dap) to harvest time

\begin{tabular}{cc}
\hline $\begin{array}{c}\text { Days after } \\
\text { planting (dap) }\end{array}$ & $\begin{array}{c}\text { Soil water content } \\
(\%)\end{array}$ \\
\hline 34 & 55.3 \\
50 & 57.9 \\
67 & 32.7 \\
73 & 35.0 \\
81 & 14.4 \\
\hline
\end{tabular}

Variance analysis showed that the lines were varied for all the mesured characters, i.e. plant height, no. of branches/plant, no. of fertile nodes/ plant, no. of full pods/ plant, no. of empty pods/ plant, flowering days, maturity days, 100 seed weight, seed yield/plant, seed yield. The different environment was only affected flowering days, 100 seed weight, seed yield/plant. Plant height, no. of empty pods/ plant, flowering days, and seed size performances were influenced by genotype $\mathrm{x}$ environment interaction (Table 2). Those characters were also reported influenced by drought imposed during generative phase on soybean $[11,12]$.

Water stress reduced number of full pods per plant by $6.3 \%$, seed yield/plant by $12.8 \%$, and seed size by $6.3 \%$ (Table 3). Du et al. [13] found that drought prevailing during generative stage, mainly at the middle and late seed filling phases, sucrose movement from leaves to seeds was lessen, and the balance of sucrose metabolism was defected in seeds, rendering in seed mass reduction. Number of full pods per plant and seed size are main attributes of soybean seed yield, the higher the number and the larger the seed size, the higher the yield $[14,15,16]$.

Number of full pods was decreased due to the abortion of younger pods and flowering halted due to drought stress. There was no significant decreased in plant height, number of branches/plants, flowering days, and maturity days, and there was an increased for number of empty pods per plant (Table 3 ). Drought was imposed at flowering stage, at that time soybean was at the maximum of vegetative growth, indicated by the average plant height and number of branches between optimal and drought conditions.

Thirty lines were tolerant to drought and early maturity in the range of 75 - 79 days, seed size between 12.0 - $16.6 \mathrm{~g} / 100$ seeds, seed yield $1.7-2.6 \mathrm{t} / \mathrm{ha}$ under optimal condition, and 1.7 - 2.4 t/ha under drought condition (Table 3). Among those lines, as many as five lines produced seed yield higher than Dering 1 with larger seed size and earlier maturity (Table 4).

Those five lines derived from different parents or gene sources, indicated large gene variability among the lines. Two lines, i.e. DM-122-35-17 and DG-24044-25 were developed using Dering 1 as female parent. Those two lines exhibited better drought tolerances and better agronomic characters (Table 4).

Table 2. Analysis of variance of seed yield and yield components of large-seeded and drought tolerant soybean lines. Ngawi, ${ }^{2 n d}$ DS 2016

\begin{tabular}{lcccc}
\hline \multicolumn{1}{c}{ Character } & $\begin{array}{c}\text { Environment } \\
(\mathbf{A})\end{array}$ & $\begin{array}{c}\text { Genotype } \\
(\mathbf{B})\end{array}$ & $\mathbf{A} \mathbf{x} \mathbf{B}$ & $\begin{array}{c}\text { Coefficient of variation } \\
(\boldsymbol{\%})\end{array}$ \\
\hline Plant height (cm) & $\mathrm{ns}$ & $* *$ & $* *$ & 7.90 \\
No. of branches/plant & $\mathrm{ns}$ & $* *$ & $\mathrm{~ns}$ & 36.03 \\
No. of fertile nodes/plant & $\mathrm{ns}$ & $* *$ & $\mathrm{~ns}$ & 23,18 \\
No. of full pods/plant & $\mathrm{ns}$ & $* *$ & $\mathrm{~ns}$ & 21.37 \\
No. of empty pods/ plant & $\mathrm{ns}$ & $* *$ & $*$ & 43.76 \\
Flowering days (days) & $* *$ & $* *$ & $* *$ & 1.39 \\
Maturity days (days) & $\mathrm{ns}$ & $* *$ & $\mathrm{~ns}$ & 1.11 \\
100 seed weight (g) & $* *$ & $* *$ & $* *$ & 7.74 \\
Seed yield/plant (g) & $*$ & $* *$ & $\mathrm{~ns}$ & 22.39 \\
Seed yield (t/ha) & $\mathrm{ns}$ & $* *$ & $\mathrm{~ns}$ & 11.40 \\
\hline Note $*$ s significantly different at $1 \%, *=$ significantly different at $5 \%, \mathrm{~ns}=\mathrm{not}$ singnificantly different
\end{tabular}

Note : $*$ significantly different at $1 \%, * *=$ significantly different at $5 \%$, ns=not singnificantly different 
Table 3. Average and reduction values of agronomic characters under optimal and drought conditions. Ngawi, ${ }^{2 n d}$ DS 2016

\begin{tabular}{lrrr}
\hline Characters & Optimal & Drought & Reduction (\%) \\
\hline Plant height (cm) & 67.94 & 67.87 & 0.11 \\
Flowering days (days) & 26.25 & 26.17 & 0.30 \\
Maturity days (days) & 76.45 & 76.16 & 0.37 \\
No. of full pods/ plant & 34.66 & 32.48 & 6.30 \\
No. of branches/plant & 1,73 & 1.56 & 10.26 \\
No. of empty pods/ plant & 1,75 & 1.70 & 2.85 \\
Seed yield/plant (g/plant) & 10.25 & 8.94 & 12.81 \\
100 seed weight (g) & 14.36 & 13.46 & 6.30 \\
Seed yield (t/ha) & 2.17 & 2.00 & 7.83 \\
\hline
\end{tabular}

Table 4. Maturity days, 100 seed weight, seed yield, stress tolerance index, and selection criteria of largeseeded and drought tolerant soybean lines. Ngawi, ${ }^{2 n d}$ DS 2016

\begin{tabular}{|c|c|c|c|c|c|c|c|}
\hline \multirow{2}{*}{ No } & \multirow{2}{*}{ Pedigree } & \multirow[b]{2}{*}{$\begin{array}{c}\text { Maturity } \\
\text { days (days) }\end{array}$} & \multirow[b]{2}{*}{$\begin{array}{c}100 \text {-seed } \\
\text { weight }(\mathrm{g})\end{array}$} & \multicolumn{2}{|c|}{ Seed yield (t/ha) } & \multirow{2}{*}{ STI } & \multirow{2}{*}{$\begin{array}{c}\text { Response } \\
\text { criteria }\end{array}$} \\
\hline & & & & Lo & $\mathbf{L 1}$ & & \\
\hline 1 & AGm-28-2-1 & 75.0 & 12.10 & 2.43 & 2.13 & 1.09 & MT \\
\hline 2 & AGm-29-3-2 & 75.0 & 12.09 & 2.15 & 2.11 & 0.96 & MT \\
\hline 3 & AB-6-52-3 & 76.3 & 15.14 & 2.12 & 1.54 & 0.69 & $\mathrm{~S}$ \\
\hline 4 & DG-94-9-4 & 75.0 & 14.46 & 2.12 & 2.07 & 0.93 & MT \\
\hline 5 & DG-97-10-5 & 75.0 & 11.37 & 1.95 & 1.94 & 0.80 & MT \\
\hline 6 & TGm-186-12-6 & 75.7 & 10.98 & 2.16 & 2.09 & 0.96 & MT \\
\hline 7 & MGm-219-16-7 & 79.0 & 11.37 & 1.74 & 2.10 & 0.77 & MT \\
\hline 8 & TGm-293-20-8 & 79.0 & 13.04 & 2.10 & 1.96 & 0.87 & MT \\
\hline 9 & AB-2-22-9 & 76.5 & 15.27 & 1.86 & 1.54 & 0.61 & $\mathrm{~S}$ \\
\hline 10 & TGm-161-25-10 & 79.0 & 12.19 & 2.60 & 2.44 & 1.35 & HT \\
\hline 11 & AB-3-51-11 & 78.0 & 15.22 & 1.92 & 1.39 & 0.57 & $\mathrm{~S}$ \\
\hline 12 & DG-75-30-12 & 75.3 & 14.38 & 2.41 & 2.11 & 1.08 & MT \\
\hline 13 & DG-88-31-13 & 75.0 & 14.47 & 2.15 & 2.08 & 0.94 & MT \\
\hline 14 & DG-99-32-14 & 75.0 & 13.13 & 2.16 & 1.98 & 0.91 & MT \\
\hline 15 & DG-100-33-15 & 75.0 & 12.14 & 2.06 & 1.81 & 0.79 & MT \\
\hline 16 & DG-102-34-16 & 75.3 & 13.14 & 1.99 & 1.78 & 0.75 & MT \\
\hline 17 & DM-122-35-17 & 75.0 & 15.42 & 2.46 & 2.44 & 1.27 & $\mathrm{~T}$ \\
\hline 18 & TGm-130-37-18 & 75.0 & 14.74 & 2.08 & 2.04 & 0.90 & MT \\
\hline 19 & TGm-288-38-19 & 75.3 & 13.56 & 2.50 & 2.32 & 1.23 & $\mathrm{~T}$ \\
\hline 20 & TGm-290-39-20 & 76.7 & 13.47 & 2.11 & 1.92 & 0.86 & MT \\
\hline 21 & AB-142-40-21 & 78.3 & 12.71 & 2.25 & 2.23 & 1.07 & MT \\
\hline 22 & AB-157-41-22 & 77.3 & 15.20 & 2.60 & 2.30 & 1.27 & $\mathrm{~T}$ \\
\hline 23 & DG-235-42-23 & 75.0 & 12.64 & 2.17 & 2.05 & 0.95 & MT \\
\hline 24 & DG-239-43-24 & 75.0 & 14.22 & 2.08 & 2.01 & 0.89 & MT \\
\hline 25 & DG-240-44-25 & 75.3 & 14.56 & 2.50 & 2.26 & 1.20 & $\mathrm{~T}$ \\
\hline 26 & DG-241-45-26 & 76.0 & 14.74 & 2.09 & 1.95 & 0.86 & MT \\
\hline 27 & DG-242-46-27 & 76.0 & 13.97 & 2.14 & 1.91 & 0.87 & MT \\
\hline 28 & DG-245-47-28 & 75.0 & 15.28 & 2.28 & 2.11 & 1.02 & MT \\
\hline 29 & DG-257-48-29 & 77.3 & 13.75 & 1.91 & 1.98 & 0.80 & $\mathrm{~S}$ \\
\hline 30 & DG-75-50-30 & 76.3 & 13.15 & 2.38 & 2.15 & 1.08 & MT \\
\hline 31 & AB-8-53-31 & 77.7 & 15.40 & 2.16 & 1.80 & 0.82 & MT \\
\hline 32 & AB-11-54-32 & 76.8 & 16.61 & 2.11 & 1.77 & 0.79 & MT \\
\hline 33 & Dering 1 & 77.3 & 11.43 & 2.11 & 2.28 & 1.02 & MT \\
\hline 34 & ARG/GCP & 80.0 & 12.23 & 2.08 & 2.04 & 0.90 & MT \\
\hline 35 & Grobogan & 75.0 & 20.60 & 2.43 & 2.02 & 1.04 & MT \\
\hline \multirow[t]{2}{*}{36} & GMI-112-17 & 77.3 & 16.66 & 1.74 & 1.42 & 0.52 & HS \\
\hline & Average & 76.3 & 13.91 & 2.17 & 2.00 & 0.93 & \\
\hline
\end{tabular}

Notes: STI=stress tolerance index, T=tolerant, HT=Highly tolerant, MT=moderately tolerant, $\mathrm{S}=$ Susceptible, HS=Highly susceptible 
Table 5. Maturity days, 100 seed weight, and seed yield of five selected drought tolerant lines. Ngawi, ${ }^{2 n d}$ DS 2016

\begin{tabular}{|c|c|c|c|c|c|c|c|}
\hline \multirow{2}{*}{ No. } & \multirow{2}{*}{ Pedigree } & \multirow{2}{*}{$\begin{array}{c}\text { Maturity } \\
\text { days } \\
\text { (days) }\end{array}$} & \multirow{2}{*}{$\begin{array}{c}100 \\
\text { seed } \\
\text { weight } \\
(\mathrm{g} \\
\end{array}$} & \multicolumn{2}{|c|}{ Seed yield (t/ha) } & \multirow{2}{*}{ STI } & \multirow{2}{*}{$\begin{array}{c}\text { Response } \\
\text { criteria }\end{array}$} \\
\hline & & & & Lo & $\mathbf{L 1}$ & & \\
\hline 1 & TGm-161-25-10 & 79 & 12,19 & 2,6 & 2,44 & 1,35 & HT \\
\hline 2 & DM-122-35-17 & 75.0 & 15.42 & 2.46 & 2.44 & 1.27 & $\mathrm{~T}$ \\
\hline 3 & TGm-288-38-19 & 75.3 & 13.56 & 2.50 & 2.32 & 1.23 & $\mathrm{~T}$ \\
\hline 4 & AB-157-41-22 & 77.3 & 15.20 & 2.60 & 2.30 & 1.27 & $\mathrm{~T}$ \\
\hline 5 & DG-240-44-25 & 75.3 & 14.56 & 2.50 & 2.26 & 1.20 & $\mathrm{~T}$ \\
\hline 6 & Dering 1 & 77.3 & 11.43 & 2.11 & 2.28 & 1.02 & MT \\
\hline 7 & Grobogan & 75.0 & 20.60 & 2.43 & 2.02 & 1.04 & MT \\
\hline
\end{tabular}

Notes: $\mathrm{L} 0=$ optimal, $\mathrm{L} 1=$ drought stress, $\mathrm{STI}=$ stress tolerance index, $\mathrm{T}=$ tolerant, $\mathrm{MT}=$ moderately tolerant

Plants show varying mechanisms to face drought stress. Drought escape admits the plant to complete its life cycle during the sufficient water supply time in advance of the drought commencement. Under the condition developing early maturity and drought tolerance lines were very effective to cope the drought stress problem.

Those five promising lines (Table 4) are interesting to be further study for their tolerance mechanism. Drought tolerance mechanism varied among tolerance genotypes, and several mechanism could be responsible for a genotype's tolerance [17, 18 , 19]. Revealing the mechanism under their tolerances would gave better handling of the lines, either to use them as new gene source or to be developed as new high yielding cultivars.

\section{CONCLUSION}

Soybean evaluation under two growing environments, i.e. optimal and drought conditions. resulted four soybean lines were more tolerant than Dering 1 (drought tolerant check), with a stress tolerance index (STI) values of 1.20 to 1.27 , which was higher than Dering 1 (STI 1.02) and Grobogan (STI 1.04). Among those four lines, AB-157-41-22 line, produced highest seed yield both in the optimal and drought conditions, i.e. $2.60 \mathrm{t} / \mathrm{ha}$ and $2.44 \mathrm{t} / \mathrm{ha}$, respectively. Those four selected drought-tolerant lines were early maturing with maturity days ranged from 75.0 to 77.3 days and three of those were belong to large seed size, i.e. $14.6-15.4 \mathrm{~g} / 100$ seeds.

\section{REFERENCES}

[1] Pusdatin, Outlook Komoditas Pertanian SubUbsektor Tanaman Pangan: Kedelai.
Pusdatin, Kementan, 2019. [In Bahasa Indonesia]

[2] K. Jumrani, V.S. Bhatia, Combined effect of high temperature and water-deficit stress imposed at vegetative and reproductive phases on seed quality in soybean, Indian Journal of Plant Physiology 23(2) (2018a) 227244.

[3] K. Jumrani, V.S. Bhatia, Impact of combined stress of high temperature and water deficit on growth and seed yield of soybean, Physiology and Molecular Biology of Plants 24(1) (2008b) 37-50. https://doi.org/10.1007/s12298-017-0480-5.

[4] E. Dogan, H. Kirnak, O. Copur, Deficit irrigations during reproductive stages and CROPGRO-soybean simulations under semiarid climatic conditions, Field Crop Research 103 (2007) 154-159.

[5] Suhartina, Evaluation of high yield and drought tolerant of black soybean lines [Evaluasi galur harapan kedelai hitam toleran kekeringan dan berdaya hasil tinggi], in:D. Harnowo et al. (Eds). Prosiding Seminar Peningkatan Produksi Kacang-kacangan dan Umbi-umbian Mendukung Kemandirian Pangan. Puslitbangtan, Bogor, 2007, pp. 153-161.

[6] R. Krisdiana, Preferensi industri tahu dan tempe dalam menggunakan bahan baku kedelai di Jawa Timur, in: A.K. Makarim, Marwoto, M.M. Adie, A.A. Rahmianna, Heriyanto, I.K. Tastra. (Eds). Kinerja Penelitian Mendukung Agribisnis Kacang-kacangan dan Umbi-umbian. Pusat Penelitian dan Pengembangan Tanaman Pangan, Bogor, 2005, pp. 540-548. [In Bahasa Indonesia]

[7] E. Ginting, Sri Satya Antarlina, Sri Widowati, Variates Unggul Kedelai Untuk Bahan Baku 
Industri Pangan, Jurnal Litbang Pertanian 28(3) (2009) 79-87. [In Bahasa Indonesia]

[8] Suhartina, Purwantoro, N. Nugrahaeni, A. Taufiq, Stabilitas hasil galur kedelai toleran cekaman kekeringan, Jurnal Penelitian Pertanian Tanaman Pangan 33(1) (2014) 54-60. [In Bahasa Indonesia]

[9] G.C.J. Fernandez, Effective selection criteria for assessing plant stress tolerance, In: C.G. Kuo. C.G. (Eds.), Adaptation of Food Crops to Temperature and Water Stress, Proceedings of An International Symposium Taiwan AVRDC, 1993, pp. 257-270.

[10] S.E. Doreste, C. Arias, A. Bellotti, Field evaluations of cassava cultivars for resistance to tetranychid mites. In: T. Brekelbaum, A. Bellotti J.C. Lazaro (Eds.) Proceedings Cassava Protection Workshop, 1979, pp.161-164.

[11] O. Basal, A. Szabó, Physiology and Yield of Three Soybean (Glycine Max (L.) Merrill) Cultivars different in Maturity Timing as Affected by Water Deficiency, LIFE: International Journal of Health and LifeSciences 4(3) (2018) 46-59. DOI: https://dx.doi.org/10.20319/lijhls.2018.43.4659.

[12] M.M. Adie, A. Krisnawati, Agronomic Characters of Drought-Tolerant Soybean at the reproductive phase, Berita Biologi 18(3) (2019) 339-345.

DOI: https://doi.org/10.14203/beritabiologi.v18i3.336 $\underline{5}$.

[13] Y. Du, Q. Zhao, L. Chen, X. Yao, H. Zhang, J. Wu, F. Xie, Effect of Drought Stress during Soybean R2-R6 Growth Stages on Sucrose Metabolism in Leaf and Seed, The International Journal of Molecular Sciences 212000618. DOI: https://doi.org/10.3390/ijms21020618

[14] N.H. Samarah, Soybean yield, yield components, seed quality, dehydrin-like proteins, soluble sugars, and mineral nutrients in response to drought stress imposed prior to severe stress, 2000. https://lib.dr.iastate.edu/rtd/12359

[15] S. Ghanbari, A. Nooshkam, B.A. Fakheri, et al. 2018. Assessment of Yield and Yield Component of Soybean Genotypes (Glycine $\operatorname{Max}$ L.) in North of Khuzestan, Journal of Crop Science and Biotechnology 21 (2018) 435-441. https://doi.org/10.1007/s12892-018-0023-0

[16] P. Preeti, R. Shrivatava, S. Nag, I. Kute, Correlation Analysis for Seed Yield and Its Attributing Traits in Soybean (Glycine max L.
Merrill), International Journal of Current Microbiology and Applied Sciences 7(4) (2018) 2034-2040.

[17] L.L. Ries, L.C. Purcell, T.E. Carter Jr, J.T. Edwards, C.A. King, Physiological Traits Contributing to Differential Canopy Wilting in Soybean under Drought, Crop Science 52 (2012) 272-281. DOI: https://doi.org/10.2135/cropsci2011.05.0278

[18] J.M. Devi, T.R. Sinclair, P. Chen, T.E. Carter, Evaluation of Elite Southern Maturity Soybean Breeding Lines for Drought-Tolerant Traits. Agronomy Journal 106 (2014) 1947-1954. DOI: https://doi.org/10.2134/agronj14.0242

[19] S.M. Pathan, J.D. Lee, D.A. Sleper, F.B. Fritschi, R.E. Sharp, T.E. Carter Jr, R.L. Nelson, C.A. King, W.T. Schapaugh, M.R. Ellersieck, H.T. Nguyen, J.G. Shannon, Two Soybean Plant Introductions Display Slow Leaf Wilting and Reduced Yield Loss under Drought, Publications from USDA-ARS/UNL Faculty, Paper 1440, 2014. http://digitalcommons.unl.edu/usdaarsfacpub/14 $\underline{40}$ 